August 2005

\title{
Expression of Imprinted Genes Is Aberrant in Deceased Newborn Cloned Calves and Relatively Normal in Surviving Adult Clones
}

Lan Yang

Pascale Chavatte-Palmer

Chikara Kubota

Michael O'neill

Thomas Hoagland

See next page for additional authors

Follow this and additional works at: https://opencommons.uconn.edu/ansc_articles

\section{Recommended Citation}

Yang, Lan; Chavatte-Palmer, Pascale; Kubota, Chikara; O'neill, Michael; Hoagland, Thomas; Renard, Jean-Paul; Taneja, Maneesh; Yang, Xiangzhong; and Tian, X Cindy, "Expression of Imprinted Genes Is Aberrant in Deceased Newborn Cloned Calves and Relatively Normal in Surviving Adult Clones" (2005). ANSC Articles. 3.

https://opencommons.uconn.edu/ansc_articles/3 
Authors

Lan Yang, Pascale Chavatte-Palmer, Chikara Kubota, Michael O'neill, Thomas Hoagland, Jean-Paul Renard, Maneesh Taneja, Xiangzhong Yang, and X Cindy Tian 


\section{Expression of imprinted genes is aberrant in deceased newborn cloned calves and relatively normal in surviving adult clones}

Lan Yang ${ }^{1}$, Pascale Chavatte-Palmer ${ }^{2}$, Chikara Kubota ${ }^{3}$, Michael O'Neill ${ }^{4}$, Thomas Hoagland ${ }^{1}$, Jean-Paul Renard ${ }^{2}$, Maneesh Taneja ${ }^{5}$, Xiangzhong Yang ${ }^{1}$, X. Cindy Tian ${ }^{1}$

${ }^{1}$ Department of Animal Science and Center for Regenerative Biology, ${ }^{4}$ Department of Molecular and Cellular Biology, University of Connecticut, Storrs, Connecticut 06269, USA

${ }^{2}$ Unit de Biologie du Developpement et Reproduction, UMR INRA/EVA n1198, 78352 Jouy en Josas, France

${ }^{3}$ Kagoshima Prefectural Cattle Breeding Development Institute, 2200 Tsukino Osumi So-Gun

$$
\begin{gathered}
\text { Kagoshima 899-8212, Japan } \\
{ }^{5} 2569 \text { Wyandotte St, Lychron, Mt. View, CA } 94043
\end{gathered}
$$

${ }^{6}$ Correspondence and reprint request: X. Cindy Tian, 1392 Storrs Road, Storrs, CT 06269-4243, Tel: 860-486-9087, Fax: 860-486-8809, e-mail: xiuchun.tian@uconn.edu.

Keywords: $H 19, \operatorname{Ig} 2$, $\operatorname{Ig} f 2 r$, imprinting, nuclear transfer, cattle 


\begin{abstract}
Cattle are the species used most frequently for the development of assisted reproductive technologies, such as nuclear transfer. Cattle cloning can be performed by a large number of 25 laboratories around the world, and the efficiency of nuclear transfer in cattle is the highest among all species in which successful cloning has been achieved. However, an understanding of the expression of imprinted genes in this important species is lacking. In the present study, real time reverse-transcription polymerase chain reaction (RT-PCR) was utilized to quantify the expression of the bovine $\operatorname{Ig} f 2, \operatorname{Ig} f 2 r$ and $H 19$ genes in eight major organs (brain, bladder, heart, 30 kidney, liver, lung, spleen and thymus) of somatic cell cloned calves that died shortly after birth, in three tissues (skin, muscle and liver) of healthy clones that survived to adulthood, and in corresponding tissues of control animals from natural reproduction. We found that, deceased bovine cloned calves exhibited abnormal expression of all three genes studied in various organs. Large variations in the expression levels of imprinted genes were also seen among these clones, which were produced from the same genetic donor. In surviving adult clones, however, the expression of these imprinted genes was largely normal, except for the expression of the $\operatorname{Ig} 2$ gene in muscle, which was highly variable. Our data showed disruptions of expression of imprinted genes in bovine clones, which is possibly due to incomplete reprogramming of donor cell nuclei during nuclear transfer, and these abnormalities may be associated with the high neonatal mortality in cloned animals; clones that survived to adulthood, however, are not only physically healthy but also relatively normal at the molecular level of those three imprinted genes.
\end{abstract}




\section{INTRODUCTION}

Since the initial report of cloning an animal from a differentiated adult somatic cell in

sheep (Wilmut et al. 1997), cloning, or somatic cell nuclear transfer, has succeeded in numerous species including the mouse (Rideout et al. 2000; Wakayama et al. 1998; Wakayama et al. 1999; Wakayama et al. 2000), cattle (Galli C 1999; Hill et al. 2000; Kato et al. 1998; Kubota et al. 2004; Kubota et al. 2000; Renard et al. 1999; Tian et al. 2000; Wells et al. 1999), goat (Keefer et al. 2002), pig (Lee et al. 2003), gaur (Vogel 2001), cat (Shin et al. 2002), mule (Woods et al. 2003), horse (Choi et al. 2002), and rat (Zhou et al. 2003). Among these species, cattle are used most often to improve nuclear transfer techniques; they have the highest nuclear transfer efficiency, and can be successfully cloned by the largest number of laboratories in the world. However, even in cattle, the cloning efficiency is normally less than 10\% (Kubota et al. 1998; Rhind et al. 2003). Additionally, symptoms of large offspring syndrome (LOS) (Young and Fairburn 2000), such as oversized calves, reluctance to suckle, difficulty breathing and standing, and greater rates of fetal and neonatal deaths, have been consistently observed in cloned cattle (Galli C 1999; Hill et al. 2000; Kato et al. 1998; Kubota et al. 2004; Kubota et al. 2000; Renard et al. 1999; Tian et al. 2000; Wells et al. 1999).

Genomic imprinting is an epigenetic mechanism by which the expression of a subset of 60 mammalian genes is dependent on whether they are inherited from the mother or the father. Most imprinted genes are involved in fetal growth regulation (Bartolomei and Tilghman 1997; Hall 1990; Jaenisch 1997; Moore and Haig 1991; Young and Fairburn 2000). To date, more than 73 imprinted genes have been identified and they code for proteins as well as conserved untranslated RNAs (Bartolomei and Tilghman 1997; Morison et al. 2001; Young and Fairburn 65 2000). In the mouse these genes include insulin-like growth factor 2 (Igf2), a paternally 
expressed fetal-specific mitogen; $\operatorname{Ig} f 2$ receptor ( $\operatorname{Ig} f 2 r$, also known as mannose 6-phosphate receptor), a maternally expressed scavenger receptor for $\operatorname{Igf2}$ (Barlow et al. 1991; Lau et al. 1994; Wang et al. 1994) which suppresses fetal growth; and $H 19$, a maternally expressed untranslated RNA believed to be important in the regulation of $\operatorname{Ig} f 2$ imprinting (Bartolomei and Tilghman 1997; Bartolomei et al. 1991; Brannan et al. 1990). The $\operatorname{Igf2}$ and $\operatorname{Ig} f 2 r$ genes are among the best studied imprinted genes involved in fetal growth regulation, and are essential for normal development (Ferguson-Smith et al. 1991; Jinno et al. 1995; Latham et al. 1994). Both the Igf2r and $\operatorname{Ig} 2$ genes are imprinted in cattle and have similar allelic expression patterns as in the mouse (Killian et al. 2001a; Killian et al. 2001b).

The developmental defects in cloned cattle, consistently observed by nearly all cloning research teams, indicate that these defects may be related to systematic mistakes of a certain set of essential growth regulating genes. Because many of these defects are similar to experimentally created imprinting disruptions (silence or biallelic expression of imprinted genes) in mice, and naturally occurring imprinting diseases in humans (Reik 1989; Reik and Constancia 1997; Young and Fairburn 2000), and most imprinted genes regulate fetal growth and many are essential (Bartolomei and Tilghman 1997; Hall 1990; Jaenisch 1997; Moore and Haig 1991), it is likely that imprinting disruptions may be associated with the defects found in clones. To this end, abnormal expression of imprinted genes has been studied in cloned mice (Humpherys et al. 2002; Inoue et al. 2002; Ogawa et al. 2003; Yamazaki et al. 2003), however, similar studies are lacking in cloned cattle.

We have generated 10 clones from an elite 13-year-old dairy cow (Xue et al. 2002), and all but one suffered from varying degrees of LOS; herein we report the levels of three imprinted genes, $\operatorname{Ig} f 2, \operatorname{Ig} f 2 r$ and $H 19$, in eight major organs of six deceased clones. To study whether or 
not expression of these imprinted genes is normal in clones that survived to adulthood, we collected biopsies of skin, muscle, and liver from six genetically identical, healthy, clones ranging from 11 to 36 months of age. We found that both normal and abnormal expression levels of imprinted genes were present in various organs of these cloned calves, and the expression levels of these imprinted genes were highly variable among animals cloned from the same donor. In the surviving adult clones, however, expression of these genes was mostly normal, indicating the aberrant expression of imprinted genes may be correlated with the death of the deceased cloned calves.

\section{MATERIALS AND METHODS}

\section{Sample collection, $R N A$ preparation, and reverse transcription polymerase chain reaction} (RT-PCR)

Organ samples were collected post-mortem from five newborn cloned calves, of a 13year old Holstein cow (Xue et al. 2002), that died shortly after birth, an additional fetus (105 days of gestation) which was a clone's clone, and five normal newborn calves from natural reproduction. Two of the clones, Clones E1 and E2, were from a twin pregnancy and another clone, Clone I, was produced from a vitrified cloned embryo. The organs sampled were brain, bladder, heart, kidney, liver, lung, spleen, and thymus.

Tissue biopsies from liver, muscle, and skin were obtained from six healthy clones that survived to adulthood. These clones were generated from fibroblast cells of an adult Holstein cow (Chavatte-Palmer et al. 2004). Briefly, the optimal intercostal liver biopsy location was determined by ultrasound imaging on the right flank. The area was prepared surgically and biopsy was performed using a percutaneous liver biopsy instrument (Bard $®$ Monopty®Billerica, 
MA, USA) under local anaesthesia. The muscle samples were collected surgically from the semitendinous muscle under local anaesthesia, at the same time as the skin samples. As controls for the adult clones, liver, skin, and muscle samples were collected at a local slaughterhouse 115 from six naturally reproduced cattle.

All samples were immediately frozen in liquid nitrogen after collection and stored at $80^{\circ} \mathrm{C}$ until RNA isolation. Total RNA was isolated using Qiagen RNeasy mini kit (Qiagen, Valencia, CA). Reverse transcription of $200 \mathrm{ng}$ of total RNA (final concentration of $10 \mathrm{ng} / \mu \mathrm{l}$ ) was conducted using Omniscript reverse transcriptase with random hexamers (Qiagen) at $37^{\circ} \mathrm{C}$

120 for 60 min. All animal procedures were approved by the Institutional Animal Use and Care Committee at the University of Connecticut and Institute National Agronomique, France.

\section{Validation of real time PCR with SYBR Green}

Real-time PCRs using ABI Prism 7000 Sequence Detection System (Applied Biosystems Inc., Foster City, CA) were carried out in a final reaction volume of $50 \mu 1$ with SYBR Green I (Qiagen), a fluorophore that binds to all double-stranded DNA. The reaction mixture contained RT products, $0.5 \mathrm{X}$ to $1 \mathrm{X}$ Q-solution depending on the gene to be amplified, $1 \mathrm{X}$ SYBR Green PCR mix and $0.3 \mu \mathrm{M}$ of each specific primer. Templates were amplified by one cycle of preincubation at $50^{\circ} \mathrm{C}$ for $2 \mathrm{~min}$ to eliminate dUMP-containing amplicons resulting from possible carryover contamination by AmpErase $\mathrm{UNG}$, and at $95^{\circ} \mathrm{C}$ for $15 \mathrm{~min}$ to activate the hotstart $T a q$ polymerase. The reaction was subsequently followed by 40 cycles of denaturation at $94^{\circ} \mathrm{C}$ for 15 sec, annealing and elongation at $61^{\circ} \mathrm{C}$ for $1 \mathrm{~min}$. The fluorescence values were determined after each elongation step. Dissociation curve analysis was performed following the final cycle to determine the specificity of the amplification. Real-time PCR products were also subjected to 
agarose gel $(1.5 \%)$ electrophoreses and stained with ethidium bromide to ensure specific amplification of a single PCR product. The primers used for PCR were: $\beta$-actin: 5'ACCGTGAGAAGATGACCCAGA-3' and 5'-TCACCGGAGTCCATCACGAT-3', Igf2r: 5'CCGGGAGATGGTAATGAGCA-3' $\quad$ and 5'-TCTCGTTCTCGTCGGCCT-3'; H19: 5'CTTGGAACACGGACTTCTTCAAG-3' and 5'-GGTCAACCTTCCAGAGCTGATT-3'; Igf2: 5'-TCTACTTCAGCCGACCATCCA-3' and 5'-GTAAGTCTCCAGCAGGGCCA-3'. The sizes of the PCR products were 101 base pairs (bp) for $\beta$-actin and Igf2, 106 bp for $H 19$ and 107 bp for $\operatorname{Ig} f 2 r$.

The comparative critical value $(\mathrm{Ct})$ method (the $2^{-\Delta \Delta \mathrm{Ct}}$ method) was applied to quantify the relative levels of mRNA using the following formula:

The relative amount of target $=2^{-\Delta \Delta C t}$, where $\mathrm{Ct}=$ threshold cycle for target amplification, $\Delta \mathrm{Ct}=\mathrm{Ct}_{\text {target gene }}-\mathrm{Ct}_{\text {internal reference, }}$ and $\Delta \Delta \mathrm{Ct}=\Delta \mathrm{Ct}_{\text {sample }}-\Delta \mathrm{Ct}_{\text {calibrator. }}$

The calibrator chosen for this study was a pooled sample of RNA from all tissues. This sample was included in every real-time amplification. The target genes were $\operatorname{Ig} f 2, \operatorname{Ig} f 2 r$ and $H 19$ and the internal reference gene was $\beta$-actin.

Validation of the amplification efficiency of imprinted genes and the internal reference gene was completed for each gene before using the $2^{-\Delta \Delta \mathrm{Ct}}$ method for quantification. Briefly, different dilutions of cDNA were amplified by real-time PCR using specific primers. The corresponding $\Delta \mathrm{Ct}$ values were plotted against the log of each cDNA amount, and the data were plotted using least-squares linear regression analysis (Fig. 1). The values of the slopes of the 155 validation curves for all genes were less than 0.1 , suggesting the same amplification efficiency was obtained for samples with both high or low amounts of target cDNA. 
After validation, the quantitative expression analysis of $\operatorname{Ig} f 2 r, \operatorname{Ig} f 2$ and $H 19$ in each tissue was conducted by using a sample of $10-40 \mathrm{ng}$ of cDNA in real-time PCR, depending on the gene to be analyzed. Each sample analysis was conducted in triplicate. The relative expression

160 level of each gene was calculated based on the expression of a calibrator, in this case a pool of RNA all tissues.

\section{Statistical analysis}

The difference in gene expression between controls and clones in specific tissues was 165 analyzed using GLM sub-routine of the Statistical Analysis System (Cary, NC), and P $<0.05$ was considered statistically significant. Homogeneity of variance between the controls and clones was determined by the ratio of the variances of the two groups, as described by Steel and Torrie (1960). The individual variances of gene expression in different tissue from each animal were compared for cloned and control cattle with a completely randomized design. Inspection of

170 the individual clones showed that specific animals had variable gene expression. A log transformation of the data reduced the differences of variance between the clones and the controls but did not change the outcome of the statistical analyses. Correlation between the expression of $H 19, \operatorname{Igf} 2$, and $\operatorname{Ig} f 2 r$ with birth weight, and the correlation of $H 19$ expression with $\operatorname{Ig} f 2$ were calculated using Microsoft Excel function CORREL and significance determined as in 175 Steel and Torrie(Steel and Torrie 1960).

\section{RESULTS}

Birth weights of deceased cloned and control calves, adult clones, as wll as the main pathological findings of the deceased cloned calves are listed in Table 1. Two clones, out of the 
five cloned calves, Clones E1 and E2 from a twin pregnancy, were 2 standard deviations (SD) below the average of all 10 clones generated from the donor animal (Xue et al. 2002), while another two (Clones F and I) were 2 SD heavier than the average birth weight of all ten clones, indicating symptoms of the LOS. All deceased cloned calves had under-developed lungs, which failed to completely inflate (atelectasis) after birth. Breathing difficulty after birth is a typical symptom of the LOS.

The expression of the $\operatorname{Ig} f 2 r$ gene in the bladder and brain of cloned calves was greater $(\mathrm{P}<0.05)$ than the expression in the same tissue from control calves (Fig. 2a). The expression of the $\operatorname{Ig} f 2 r$ gene in all the other tissues was similar for cloned and control calves. In general, the expression of $\operatorname{Ig} f 2 r$ in controls was relatively uniform with a coefficient of variance (CV) of $33 \%$, while in cloned animals, even though from the same genetic donor, large variations $(\mathrm{CV}=100 \%)$ were found which are significantly different $(\mathrm{P}<0.001)$. The variance within the clone group was greater than that in the control group for some tissues and genes as indicated by a significant increase $(\mathrm{P}<0.001)$ in the variances of the gene expressions in the clones as compared to controls. Despite no significant differences found between controls and clones in $\operatorname{Ig} f 2 r$ gene expression in 195 most tissue, individual clones showed extremely high expression in some tissues, as evidenced by the large standard error bars for the clones (Fig. 2a). For instance, Clone E2 had 10 times more $\operatorname{Ig} f 2 r$ gene expression in the heart, liver, and spleen than the average expression levels of the controls. Clone E1 expressed 7 times more $\operatorname{Ig} f 2 r$ in the heart, spleen, and thymus, and Clone F had 5 times more expression in the spleen and thymus than the average of the controls.

The $\operatorname{Ig} f 2$ gene was significantly over-expressed by clones in heart, kidney, lung, and spleen compared to that in controls (Fig. 2b). The variations of $\operatorname{Ig} f 2$ gene expression in the control and clone groups were similar to those of the $\operatorname{Igf} 2 r$ gene, i.e., uniform in controls while 
highly variable in clones. Examples are: Clone E1 had approximately 7 times, and E2 20 times more $\operatorname{Ig} 2$ gene expression in their bladders than the average level of the controls.

The untranslated, imprinted gene in cattle, H19, was significantly over expressed in the bladder, brain, heart, and lung of all clones (Fig. 2c) compared to the expression in these tissues of control calves. Clones E1, E2, and F had 10 times greater expression of H19 in spleen than controls, while Clones E2 and F had approximately 30 and 8 times more expression, respectively, in the liver, when compared to the average of controls.

Because $H 19$ is believed to regulate expression of $\operatorname{Igf2}$ in the mouse and human, we also determined the correlation between the expression of these two genes. The expression of $\operatorname{Ig} f 2$ and $H 19$ genes were positively correlated in both controls $(\mathrm{r}=0.895 ; \mathrm{P}<0.01)$ and cloned calves $(\mathrm{r}=0.702 ; \mathrm{P}<0.01)$. However, we were unable to find a significant correlation between birth weights and the expression of any gene examined.

In clones that survived to adulthood, the expression levels of all genes were similar to those of controls in all tissues, with the exception of the levels of Igf2 in muscles, which clones over-expressed $(\mathrm{P}<0.01)$, compared to controls (Fig. 3b), and the expression levels were highly variable. Gene expression in muscle was also found highly variable in both control calves and adults. Interestingly, the levels of $\operatorname{Ig} f 2$ and $H 19$ gene expression were significantly higher in newborn controls than in adult controls, reflecting the need for a greater amount of the growthenhancing $\operatorname{Ig} f 2$ during the post-natal growth period. In contrast to newborn calves, we found a very low correlation between the levels of expression of $I g f 2$ and $H 19$ in adult control animals (r $=0.013 ; \mathrm{P}>0.05)$. 
In the present study, we determined expression levels of $\operatorname{Ig} f 2, \operatorname{Ig} f 2 r$, and $H 19$ in organs of newborn and adult cattle from natural reproduction and from nuclear transfer. We conclude that ten of the 24 parameters analyzed in calves (three genes in eight organs) and one of the nine measured in adults ( 3 genes in three tissues), were abnormal. For all of these 11 abnormal 230 parameters, clones had significantly greater gene expression than controls. In general, we also found that the expression levels of the three genes were more variable in clones than controls, except for the expression of Igf2 in adult muscles, which was also highly variable in controls.

The large variation of $\operatorname{Ig} f 2 r$ expression in clones made it difficult to obtain statistically significant differences, except for the expression in tissue from bladders and brains. Previously, 235 expression levels of $\operatorname{Ig} f 2 r$ have been measured in mice cloned from somatic or embryonic stem (ES) cells, and in cloned bovine embryos. Both normal (Humpherys et al. 2002; Inoue et al. 2002) and reduced levels of $I g f 2 r$ expression have been reported in the placenta of mice cloned from somatic cells (Inoue et al. 2002). In cloned bovine embryos, expression of $\operatorname{Ig} f 2 r$ was found statistically indifferent from that of controls from in vitro fertilization (IVF) (Han et al. 2003), 240 and largely agreed with the results for full term cloned calves of the present study.

Contrary to the similarities in expression levels of the $\operatorname{Ig} f 2 r$ gene, the levels of $\operatorname{Ig} f 2$ mRNA were significantly higher in cloned, compared to control calves, in multiple tissues including hearts, kidneys, lungs, and spleens. A previous study in cloned bovine embryos also showed higher expression of Igf2, when compared to IVF controls (Han et al. 2003). The 245 abnormally higher levels of expression of this gene in deceased full-term clones was much more severe than its scavenger receptor gene, indicating an overall fetal growth promoting effect, rather than an inhibiting effect, in these clones. In cloned mice, conflicting data have been 
reported for $\operatorname{Ig} 22$ expression. For instance, $\operatorname{Ig} 2 \mathrm{mRNA}$ levels were found elevated in the liver of mouse ES clones (Humpherys et al. 2002); reduced in fetuses and placenta of ES clones (Ogawa et al. 2003); and not different in the placentas of ES (Humpherys et al. 2002) and somatic clones (Inoue et al. 2002) compared to naturally reproduced control mice. These discrepancies may reflect the large variations in gene expression in individual cloned mice, which was also seen in cloned calves in the present study. The documented differences in gene expression from clones of different species, and clones of the same species, further suggests the incomplete and random nature of gene reprogramming in both the mouse and bovine.

In this study, we also determined the expression level of H19. This is because the H19 and $I g f 2$ genes are closely linked, and $H 19$ contains the imprinting control element for $I g f 2$ in the human and mouse (Wutz and Barlow 1998; Young et al. 2003). It is known that $H 19$ is also linked to $\operatorname{Ig} 2$ in the bovine (Larkin et al. 2003), however, the mechanism of imprinting control 260 for $\operatorname{Ig} 2 \mathrm{2}$ by $H 19$ has not been established. We found that expression levels of $H 19$ were more variable and were significantly higher, in 4 out of 8 cloned calves' organs, than in controls. In mouse ES clones, levels of $H 19$ expression were also highly variable and, as for the expression of the $\operatorname{Ig} 2 \mathrm{~g}$ gene, the findings are controversial. $H 19$ has been found reduced in the fetuses and placenta (Ogawa et al. 2003) and in the livers of ES clones (Humpherys et al. 2001), not different

265 from controls in the placenta in somatic cell clones (Inoue et al. 2002), and silenced in placenta of ES clones (Humpherys et al. 2001). However, cloned mice did not show higher H19 expression than control mice, which we did find in the cloned calves. This may indicate species differences.

In mice from natural reproduction, expression of $H 19$ and $I g f 2$ is negatively correlated 270 (Li et al. 1993). A similar negative relationship was also found in mouse embryos cloned from 
ES cells. These cloned mice had relatively low expression of $H 19$ and an over expression of Igf 2 (Humpherys et al. 2001). However, this reciprocal expression of $H 19$ and $\operatorname{Ig} f 2$ was not always observed in each cloned mouse (Humpherys et al. 2001). In the present study, we found a positive correlation between the expression of $\operatorname{Ig} f 2$ and $H 19$ in both somatic cloned and control calves, which indicates an interaction between the regulations of these 2 genes. This positive correlation, however, suggests a possible difference in the mechanisms of $\operatorname{Ig} 2$ and $H 19$ imprinting regulation between cattle and mice.

In IVF sheep with LOS, no aberrant levels of $\operatorname{Ig} 2$ expression were found, while there were reduced expression levels of $I g f 2 r$ in various organs (Young et al. 2001). Because $I g f 2 r$ inhibits fetal growth, reduced $\operatorname{Ig} f 2 r$ would have less growth suppression effect and therefore was believed to be one of the mechanisms for LOS in sheep. In the present study, although the cloned calves survived to near or full term, they suffered various symptoms of LOS, and died shortly after birth. We found an overall higher expression of $\operatorname{Ig} f 2$ in these calves compared to the controls, suggesting that, in these animals, Igf 2 may be correlated with LOS. However, we did not find a strong correlation between the birth weights of these deceased clones with the expression levels of $\operatorname{Ig} 2 r$ in their organs. For instance, two of the cloned animals, Clones I and F, were abnormally "large" (2 SD more than the mean birth weights of all clones). Clone I, produced from a vitrified cloned embryo, suffered the most severe form of LOS, and died in a veterinary hospital despite intensive care. Yet, neither Clone F nor I had particularly abnormal $\operatorname{Ig} f 2 r$ expression. The only animal in which there may be a negative correlation between $\operatorname{Ig} f 2 r$ expression and birth weight is Clone E2, who had the highest levels of $\operatorname{Ig} 22 r$ in most of her organs, including brain, heart, liver, lung, and spleen, and was the smallest clone produced from this donor. It is possible that the high $\operatorname{Igf} 2 r$ levels inhibited her growth. Nonetheless, the 
abnormal expression of imprinted genes could have contributed to the clones' death, although a

295 few genes cannot be correlated to a complex syndrome such as LOS, which is likely the result of the combined effect of the aberrant expression of many genes.

In contrast to newborn calves, clones that survived to adulthood, even those that suffered some forms of LOS at birth, appear to be more or less normal in the expression of the three imprinted genes studied. Among all parameters analyzed, only one of them, $\operatorname{Ig} f 2$ in muscle, was significantly different between adult controls and adult clones, indicating cloned animals that survived are not only generally healthy, but are also relative normal at the molecular level of those imprinted genes.

\section{Acknowledgements}

We thank David Schreiber, Charlie Bormann, Jeremy Chang, J. Slizs, Sanjeev Chaubal, Drs. John Riesen and Jie Xu for sample collection, Marina. Julian for manuscript editing, Jie He for $\beta$-actin primers, and Drs. Chris Miller, Hong Xie and Peter Harris of ABI for technical assistance with the real-time PCR.

\section{References:}


Barlow DP, Stoger R, Herrmann BG, Saito K, Schweifer N. 1991. The mouse insulin-like growth factor type- 2 receptor is imprinted and closely linked to the Tme locus. Nature 349(6304):84-87.

Bartolomei MS, Tilghman SM. 1997. Genomic imprinting in mammals. Annu Rev Genet $31: 493-525$.

Bartolomei MS, Zemel S, Tilghman SM. 1991. Parental imprinting of the mouse H19 gene. Nature 351(6322):153-155.

Brannan CI, Dees EC, Ingram RS, Tilghman SM. 1990. The product of the H19 gene may function as an RNA. Mol Cell Biol 10(1):28-36.

Chavatte-Palmer P, Remy D, Cordonnier N, Richard C, Issenman H, Laigre P, Heyman Y, Mialot JP. 2004. Health status of cloned cattle at different ages. Cloning Stem Cells 6(2):94-100.

Choi YH, Love CC, Chung YG, Varner DD, Westhusin ME, Burghardt RC, Hinrichs K. 2002. Production of nuclear transfer horse embryos by Piezo-driven injection of somatic cell nuclei and activation with stallion sperm cytosolic extract. Biol Reprod 67(2):561-567.

Ferguson-Smith AC, Cattanach BM, Barton SC, Beechey CV, Surani MA. 1991. Embryological and molecular investigations of parental imprinting on mouse chromosome 7. Nature 351(6328):667-670.

Galli C RD, RM Moor and G Lazzari. 1999. Mammalian leukocytes contain all the genetic information necessary for the development of a new individual. Cloning(3):161-170.

Hall JG. 1990. Genomic imprinting: review and relevance to human diseases. Am J Hum Genet 46(5):857-873. 
Han DW, Song SJ, Uhum SJ, Do JT, Kim NH, Chung KS, Lee HT. 2003. Expression of IGF2 and IGF receptor mRNA in bovine nuclear transferred embryos. Zygote 11(3):245-252.

Hill JR, Winger QA, Long CR, Looney CR, Thompson JA, Westhusin ME. 2000. Development rates of male bovine nuclear transfer embryos derived from adult and fetal cells. Biol Reprod 62(5):1135-1140.

Humpherys D, Eggan K, Akutsu H, Friedman A, Hochedlinger K, Yanagimachi R, Lander ES, Golub TR, Jaenisch R. 2002. Abnormal gene expression in cloned mice derived from embryonic stem cell and cumulus cell nuclei. Proc Natl Acad Sci U S A 99(20):1288912894.

Humpherys D, Eggan K, Akutsu H, Hochedlinger K, Rideout WM, 3rd, Biniszkiewicz D, Yanagimachi R, Jaenisch R. 2001. Epigenetic instability in ES cells and cloned mice. Science 293(5527):95-97.

Inoue K, Kohda T, Lee J, Ogonuki N, Mochida K, Noguchi Y, Tanemura K, Kaneko-Ishino T, Ishino F, Ogura A. 2002. Faithful expression of imprinted genes in cloned mice. Science 295(5553):297.

Jaenisch R. 1997. DNA methylation and imprinting: why bother? Trends Genet 13(8):323-329.

Jinno Y, Ikeda Y, Yun K, Maw M, Masuzaki H, Fukuda H, Inuzuka K, Fujishita A, Ohtani Y, Okimoto T, et al. 1995. Establishment of functional imprinting of the H19 gene in human developing placentae. Nat Genet 10(3):318-324.

Kato Y, Tani T, Sotomaru Y, Kurokawa K, Kato J, Doguchi H, Yasue H, Tsunoda Y. 1998. Eight calves cloned from somatic cells of a single adult. Science 282(5396):2095-2098. 
Keefer CL, Keyston R, Lazaris A, Bhatia B, Begin I, Bilodeau AS, Zhou FJ, Kafidi N, Wang B, Baldassarre H, Karatzas CN. 2002. Production of cloned goats after nuclear transfer using adult somatic cells. Biol Reprod 66(1):199-203.

Killian JK, Nolan CM, Stewart N, Munday BL, Andersen NA, Nicol S, Jirtle RL. 2001 a. Monotreme IGF2 expression and ancestral origin of genomic imprinting. J Exp Zool 291(2):205-212.

Killian JK, Nolan CM, Wylie AA, Li T, Vu TH, Hoffman AR, Jirtle RL. 2001b. Divergent evolution in M6P/IGF2R imprinting from the Jurassic to the Quaternary. Hum Mol Genet 10(17):1721-1728.

Kubota C, Tian XC, Yang X. 2004. Serial bull cloning by somatic cell nuclear transfer. Nat Biotechnol 22(6):693-694.

365 Kubota C, Yamakuchi H, Todoroki J, Mizoshita K, Tabara N, Barber M, Yang X. 2000. Six cloned calves produced from adult fibroblast cells after long-term culture. Proc Natl Acad Sci U S A 97(3):990-995.

Kubota C, Yang X, Dinnyes A, Todoroki J, Yamakuchi H, Mizoshita K, Inohae S, Tabara N. 1998. In vitro and in vivo survival of frozen-thawed bovine oocytes after IVF, nuclear transfer, and parthenogenetic activation. Mol Reprod Dev 51(3):281-286.

Larkin DM, Everts-van der Wind A, Rebeiz M, Schweitzer PA, Bachman S, Green C, Wright CL, Campos EJ, Benson LD, Edwards J, Liu L, Osoegawa K, Womack JE, de Jong PJ, Lewin HA. 2003. A cattle-human comparative map built with cattle BAC-ends and human genome sequence. Genome Res 13(8):1966-1972. 
Latham KE, Doherty AS, Scott CD, Schultz RM. 1994. Igf2r and Igf2 gene expression in androgenetic, gynogenetic, and parthenogenetic preimplantation mouse embryos: absence of regulation by genomic imprinting. Genes Dev 8(3):290-299.

Lau MM, Stewart CE, Liu Z, Bhatt H, Rotwein P, Stewart CL. 1994. Loss of the imprinted IGF2/cation-independent mannose 6-phosphate receptor results in fetal overgrowth and perinatal lethality. Genes Dev 8(24):2953-2963.

Lee JW, Wu SC, Tian XC, Barber M, Hoagland T, Riesen J, Lee KH, Tu CF, Cheng WT, Yang X. 2003. Production of cloned pigs by whole-cell intracytoplasmic microinjection. Biol Reprod 69(3):995-1001.

Li E, Beard C, Jaenisch R. 1993. Role for DNA methylation in genomic imprinting. Nature 366(6453):362-365.

Moore T, Haig D. 1991. Genomic imprinting in mammalian development: a parental tug-of-war. Trends Genet 7(2):45-49.

Morison IM, Paton CJ, Cleverley SD. 2001. The imprinted gene and parent-of-origin effect database. Nucleic Acids Res 29(1):275-276.

390 Ogawa H, Ono Y, Shimozawa N, Sotomaru Y, Katsuzawa Y, Hiura H, Ito M, Kono T. 2003. Disruption of imprinting in cloned mouse fetuses from embryonic stem cells. Reproduction 126(4):549-557.

Reik W. 1989. Genomic imprinting and genetic disorders in man. Trends Genet 5(10):331-336. Reik W, Constancia M. 1997. Genomic imprinting. Making sense or antisense? Nature 389(6652):669-671.

Renard JP, Chastant S, Chesne P, Richard C, Marchal J, Cordonnier N, Chavatte P, Vignon X. 1999. Lymphoid hypoplasia and somatic cloning. Lancet 353(9163):1489-1491. 
Rhind SM, Taylor JE, De Sousa PA, King TJ, McGarry M, Wilmut I. 2003. Human cloning: can it be made safe? Nat Rev Genet 4(11):855-864.

400 Rideout WM, 3rd, Wakayama T, Wutz A, Eggan K, Jackson-Grusby L, Dausman J, Yanagimachi R, Jaenisch R. 2000. Generation of mice from wild-type and targeted ES cells by nuclear cloning. Nat Genet 24(2):109-110.

Shin T, Kraemer D, Pryor J, Liu L, Rugila J, Howe L, Buck S, Murphy K, Lyons L, Westhusin M. 2002. A cat cloned by nuclear transplantation. Nature 415(6874):859.

405 Steel RGD, Torrie JH. 1960. Principles and Procedures of Statistics. New York: McGraw-Hill Book Co.

Tian XC, Xu J, Yang X. 2000. Normal telomere lengths found in cloned cattle. Nat Genet 26(3):272-273.

Vogel G. 2001. Endangered species. Cloned gaur a short-lived success. Science 291(5503):409.

410 Wakayama T, Perry AC, Zuccotti M, Johnson KR, Yanagimachi R. 1998. Full-term development of mice from enucleated oocytes injected with cumulus cell nuclei. Nature 394(6691):369-374.

Wakayama T, Rodriguez I, Perry AC, Yanagimachi R, Mombaerts P. 1999. Mice cloned from embryonic stem cells. Proc Natl Acad Sci U S A 96(26):14984-14989.

415 Wakayama T, Tateno H, Mombaerts P, Yanagimachi R. 2000. Nuclear transfer into mouse zygotes. Nat Genet 24(2):108-109.

Wang ZQ, Fung MR, Barlow DP, Wagner EF. 1994. Regulation of embryonic growth and lysosomal targeting by the imprinted Igf2/Mpr gene. Nature 372(6505):464-467.

Wells DN, Misica PM, Tervit HR. 1999. Production of cloned calves following nuclear transfer 420 with cultured adult mural granulosa cells. Biol Reprod 60(4):996-1005. 
Wilmut I, Schnieke AE, McWhir J, Kind AJ, Campbell KH. 1997. Viable offspring derived from fetal and adult mammalian cells. Nature 385(6619):810-813.

Woods GL, White KL, Vanderwall DK, Li GP, Aston KI, Bunch TD, Meerdo LN, Pate BJ. 2003. A mule cloned from fetal cells by nuclear transfer. Science 301(5636):1063.

Wutz A, Barlow DP. 1998. Imprinting of the mouse Igf2r gene depends on an intronic CpG island. Mol Cell Endocrinol 140(1-2):9-14.

Xue F, Tian XC, Du F, Kubota C, Taneja M, Dinnyes A, Dai Y, Levine H, Pereira LV, Yang X. 2002. Aberrant patterns of $X$ chromosome inactivation in bovine clones. Nat Genet 31(2):216-220.

Yamazaki Y, Mann MR, Lee SS, Marh J, McCarrey JR, Yanagimachi R, Bartolomei MS. 2003. Reprogramming of primordial germ cells begins before migration into the genital ridge, making these cells inadequate donors for reproductive cloning. Proc Natl Acad Sci U S A 100(21):12207-12212.

Young LE, Fairburn HR. 2000. Improving the safety of embryo technologies: possible role of genomic imprinting. Theriogenology 53(2):627-648.

Young LE, Fernandes K, McEvoy TG, Butterwith SC, Gutierrez CG, Carolan C, Broadbent PJ, Robinson JJ, Wilmut I, Sinclair KD. 2001. Epigenetic change in IGF2R is associated with fetal overgrowth after sheep embryo culture. Nat Genet 27(2):153-154.

Young LE, Schnieke AE, McCreath KJ, Wieckowski S, Konfortova G, Fernandes K, Ptak G, Kind AJ, Wilmut I, Loi P, Feil R. 2003. Conservation of IGF2-H19 and IGF2R imprinting in sheep: effects of somatic cell nuclear transfer. Mech Dev 120(12):14331442. 
Zhou Q, Renard JP, Le Friec G, Brochard V, Beaujean N, Cherifi Y, Fraichard A, Cozzi J. 2003. Generation of fertile cloned rats by regulating oocyte activation. Science 302(5648):1179. 


\section{Figure legends}

Fig. 1. A representative validation curve of real time RT-PCR for the $\operatorname{Ig} f 2 r$ gene. a) The amplification plot of $\operatorname{Ig} 2 \mathrm{r}$ with RNA diluted from $10 \mathrm{ng}$ to $0.5 \mathrm{ng}$. b) The dissociation curve of PCR products for $I g f 2 r$. Only one dissociation temperature was observed, demonstrating that the amplification is specific to one PCR product. c) The validation curve for multiple dilutions of RNA. The slope of the curve was $<0.1$, demonstrating that the same efficiency has been achieved for samples with different amounts of $\operatorname{Ig} f 2 r$ mRNA.

455 Fig. 2. Relative levels of expression, expressed as folds over the calibrator, for a) $\operatorname{Ig} f 2 r$, b) $\operatorname{Ig} f$, and c) H19 in organs/tissues of deceased cloned (black bars) and live control newborn calves (open bars). Bars with different superscripts are significantly different within the tissue $(\mathrm{p}<0.05)$.

Fig. 3. Relative levels of expression for a) $\operatorname{Ig} f 2 r$, b) $\operatorname{Ig} f$, and c) $H 19$ in liver, muscle and skin of newborn controls (open bars), adult controls (dotted bars) and live adult clones (gridded bars). Bars with different superscripts are significantly different within the tissue $(\mathrm{p}<0.05)$ 